\title{
Editor's Note to the Present Revision
}

$\mathrm{P}$ ROFESSOR FLORIAN CAJORI died August 14, 1930. In May of the following year I was invited by the University of California Press to edit this work. After much delay, due in part to unavoidable circumstances and in part to the time consumed in the extraordinary care taken in reading, checking, and rereading the proofs, this edition of Newton's Principia is now ready to be run off the press.

The manuscript as presented to the Press contained no Preface. Much of the material that would be included in the usual Preface is contained in the first few notes of the Appendix, pages $627 \mathrm{ff}$. Professor Cajori probably intended to prepare a Preface while the book was in the process of manufacture. There being none, the customary acknowledgment of thanks to various persons who assisted him in one way or another is lacking. Lest I unknowingly omit some to whom thanks are due, I refrain from attempting any such acknowledgment on behalf of the author.

As the title page states, this is a revision of Motte's translation of the Principia. From many conversations with Professor Cajori, I know that he had long cherished the idea of revising Newton's immortal work by rendering certain parts into modern phraseology (e.g., to change the reading of "reciprocally in the subduplicate ratio of" to "inversely as the square root of") and to append historical and critical notes which would provide instruction to some readers and interest to all. This is his last work; one most fitting to crown a life devoted to investigation and to writing the history of the sciences in his chosen field.

R. T. CRAWFord

Berkeley, California,

March 31, I934. 
